be required to prove them so. Laboratory experiments are far more reliable.

E. G. Mahin,

Purdue University R. H. Carr

\section{NOTE ON A DAYLIGHT METEORITE}

THINkING that it might be of interest to readers of these columns, the writer calls attention to the following phenomenon observed by him while traveling by canoe on Lake Kipawa, Quebec, on August 31 last.

The day was particularly bright and cloudless, with a southerly wind blowing at about eight miles an hour. The time of the observation was 9:50 a. m., and the course of the canoe was almost directly south. The meteorite was suddenly seen to shoot across the course of the canoe from east to west, about $50^{\circ}$ above the horizon, and, as far as could be judged, between 200 and 300 feet above the surface of the lake. Its passage lasted approximately three seconds from the time that it was first noted a little to the left of the bow of the canoe. The general impression received was that of a brilliant Roman candle shooting across the sky, of a vivid copper-green color. The size of the incandescent head of the body appeared to be a trifle larger than a golf ball with a bright incandescent streamer of nearly three feet in length behind it and of a like color. In the wake of the body trailed a curling wreath of white vapor of considerable length which became quickly dissipated.

The passage of the meteorite was accompanied by no detectable noise whatever, so that the other occupant of the canoe, whose gaze was dirceterl elsewhere at the time, failed to see the occurrence. The body suddenly vanished about a hundred yards to the west about the original altitude, leaving a small cloud of white vapor behind that dissolved rapidly away. Although watch was kept on the surface of the lake beyond, no trace of a body falling into the water was noted. It is possible that either it was completely combusted at that moment, or it passed out of sight rapidly along its westerly course.

\section{Norman MacL. Harris}

Departinent of Health of Canada, OTTAWA, ONTARIo
HOWARD ON CHEMICAL SPELLING

O Leland tell me, tell me true, The explanation's up to you, Why did you break the portals down And jump into the Chemist's town? But wait a minute: Now I see, To solve the riddle's up to me; You still are in your own domain Where you without a rival reign, For as the fact appears to me You're trying to catch that spelling bee.

H. W. WILEY

\section{QUOTATIONS}

\section{"BAYER 205"}

A currous illustration of the German desire, not unnatural in itself, to regain the tropical colonies lost by the folly of the rulers of the German Empire, is afforded by a discussion which took place at a meeting of the German Association of Tropical Medicine at Hamburg. We have not seen a full report of the meeting, but the Times correspondent in Hamburg reports that one of the speakers said that "Bayer 205 is the key to tropical Africa, and consequently the key to all the colonies. The German government must, therefore, be required to safeguard this discovery for Germany. Its value is such that any privilege of a share in it granted to other nations must be made conditional upon the restoration to Germany of her colonial empire." Some account of the drug manufactured by the Bayerische Farbwerke and provisionally named "205" was given in our issue of May 20 (p. 807), when we quoted Dr. H. H. Dale's opinion that it was a remarkable curative agent in trypanosome infections. A general account of the probable chemical relationship of "205" is given by $\mathrm{Dr}$. King in the sixth Annual Report of the Society of Chemical Industry (1921).

In 1904 Ehrlich and Shiga discovered the trypanocidal action of trypan red, a compound formed by combining one molecule of tetrazotized benzidine-mono-sulfonic acid with two molecules of sodium naphthylamine disulfonate. In 1906 Mesnil and Nicolle ${ }^{1}$ invesitigated a series of dyes containing amino-naph-

1 Ann. Instit. Pasteur, 417 and 518. xx, 1906. 